BARBARA BATKO-TOKARZ ${ }^{\star} \mid$ UNIWERSYTET JAGIELLOŃSKI

\title{
Bożena Sieradzka-Baziur, Onomazjologiczny słownik online. Metodologia, zawartość, wykorzystanie w badaniach na przykładzie Słounika pojęciouego języka staropolskiego
}

INSTYTUT JĘZYKA POLSKIEGO POLSKIEJ AKADEMII NAUK, KRAKÓW 2O2O, S. 154

doi: http://dx.doi.org/10.31286/JP.101.3.12

Już w samym tytule recenzowanej książki zawarte jest to, co wydaje się w niej szczególnie wartościowe. Dotyczy ona słownika onomazjologicznego, a ściślej: pojęciowego o hierarchicznym układzie semantycznym, który ma formę słownika online. Takim właśnie dziełem leksykograficznym jest stworzony na podstawie Stownika staropolskiego dostępny tylko elektronicznie Stownik pojęciowy języka staropolskiego (SPJS). Recenzowana książka, która została wydana dopiero po pięciu latach od początku funkcjonowania sPJs, opisuje zarówno jego założenia metodologiczne, jak i ich praktyczną realizację. Bardzo dobrze, że jej autorka, będąca kierownikiem tego słownika, zaprezentowała taki opis. Choć wraz z zespołem wydawała różnorodne artykuły naukowe na temat SPJs, brakowało całościowej prezentacji podstaw teoretycznych tego opracowania leksykograficznego ciekawego i wartościowego zarówno ze względu na jego formę, jak i dużą użyteczność w badaniach leksyki staropolskiej. Choć niekoniecznie z książki skorzysta przeciętny użytkownik SPJS ${ }^{1}$, opis ten jest bardzo przydatny dla badaczy zajmujących się semantyką historyczną czy słownikami onomazjologicznymi, szczególnie że prezentowane podstawy teoretyczne publikacji zostały zweryfikowane w praktyce leksykograficznej.

Podjęcie tej tematyki jest szczególnie ważne właśnie ze względu na leksykografię onomazjologiczną, której wciąż poświęca się zbyt mało uwagi zarówno w badaniach polskich, jak i europejskich. Jak się wydaje, na początku XxI wieku zaczyna ona jednak przeżywać swoisty renesans. Dzieje się to na skutek zastosowania w leksykografii nowoczesnych narzędzi informatycznych i różnorodnych kryteriów wyszukiwania, w tym kryterium znaczeniowego, które można łatwo połączyć z układem alfabetycznym. Świetnymi tego przykładami poza sPJs są także inne współczesne słowniki wymienione w książce Historical Thesaurus of the Oxford English Dictionary oraz Wielki słownik języka polskiego PAN. W najbliższej przyszłości można się spodziewać nowych opracowań leksykograficznych wprowadzających na różne sposoby semantyczny układ słownictwa, dlatego warto poświęcać więcej uwagi kwestiom teoretycznym związanym $\mathrm{z}$ ich budową i funkcjonowaniem.

\footnotetext{
* barbara.batko-tokarz@uj.edu.pl; ORCID: oooo-ooo1-9147-5180

1 Może skorzystałby bardziej, gdyby na przykład jej skrócona wersja pojawiła się na stronie internetowej SPJS w zakładce O stowniku.
} 
Poza wstępem i zakończeniem książka składa się z trzech rozdziałów. W pierwszym opisano pokrótce onomazjologię jako dział leksykografii i jej stosunek do teorii pola semantycznego, a także najbardziej znane słowniki onomazjologiczne, zarówno polskie, jak i obce. Autorka zdecydowała się na określenie słownik onomazjologiczny zapewne także ze względu na mnogość terminologii stosowanej w stosunku do tego typu słowników w leksykografii polskiej i europejskiej. Jak zauważa, jest ono nadrzędne wobec takich terminów, jak słownik tematyczny, rzeczowy czy pojęciowy ${ }^{2}$ (używanych w polskiej leksykografii najczęściej), przy czym trzeba zauważyć, że mieści w sobie także słowniki synonimów. Na uwagę w tym rozdziale zasługuje też krótka analiza porównawcza opisu pojęcia emocje w różnych słownikach tego rodzaju, która dobrze pokazuje subiektywność podziałów według kryterium znaczeniowego i różnorodność pomysłów na ich przeprowadzenie.

W rozdziale drugim, pt. Stownik pojęciowy języka staropolskiego jako słownik onomazjologiczny, zamieszczono natomiast opis zawartości słownika oraz jego rozbudowanej makroi mikrostruktury. Znaleźć w nim możemy obszerne wyjaśnienie terminologii stosowanej w SPJS, a także opis jego elementów stałych i zmiennych. Zaletami formy elektronicznej tego dzieła leksykograficznego są opisane w rozdziale możliwości wprowadzania ciągłych modyfikacji oraz korzystania ze słownika również w układzie alfabetycznym i gramatycznym.

Najbardziej rozbudowany jest rozdział trzeci - Schemat klasyfikacyjny jako kluczowy element SPJS. Autorka opisuje w nim procesy zarówno przyporządkowywania autosemantycznej jednostki leksykalnej do pojęcia, jak i tworzenia schematu klasyfikacyjnego. Tłumaczy też, dlaczego w tym celu zdecydowała się na adaptację schematu Rudolfa Halliga i Walthera von Wartburga, mimo że - jak pisze - od początku było jasne, iż będzie on stanowił tylko punkt wyjścia. Następnie możemy przeczytać o wyraźnych różnicach między tymi dwoma schematami pojęciowymi, zarówno zewnętrznych, jak i bardziej zasadniczych, odnoszących się do odmiennego ukształtowania pojęć i liczby poziomów kategoryzacyjnych. Trudno na tym etapie odpowiedzieć na pytanie, czy nie łatwiej byłoby stworzyć oryginalny schemat klasyfikacyjny na podstawie oddolnej analizy średniowiecznego materiału językowego. Na pewno jednak, moim zdaniem, właściwe było wybranie spośród innych klasyfikacji schematu R. Halliga i W. von Wartburga ze względu na jego dużą uniwersalność i funkcjonalność. Wybrana metoda budowy SPJs, łącząca w sobie oddolny i odgórny sposób budowania siatki pojęciowej, okazała się również skuteczna. Należy przy tym docenić żmudny proces dopasowywania schematu opracowanego z myślą o współczesnym języku francuskim do specyfiki materiału staropolskiego, dzięki czemu struktura pojęciowa, która powstała, jest ciekawa, funkcjonalna i w wielu miejscach różna od oryginału, a co najważniejsze, umożliwia skuteczną klasyfikację leksyki średniowiecznej.

Zagadnienia te rozwija autorka w dalszej części rozdziału, pisząc o konceptualizacji strukturyzującej i problemach wynikających z adaptacji xx-wiecznego schematu do analizy języka staropolskiego. Choć cechą tego typu klasyfikacji jest bardziej lub mniej, ale jednak skojarzeniowy

2 To określenie w polskiej leksykografii funkcjonowało do tej pory w opisach teoretycznych, dopiero autorzy sPJS zastosowali je w nazwie słownika, co moim zdaniem jest w kontekście jego formy bardzo uzasadnione. 
charakter przyporządkowań, autorzy SPJS mieli szczególnie trudne zadanie, zważywszy na typ słownictwa poddanego podziałowi. Pojawiła się choćby opisana w tej części książki wątpliwość, w jakim stopniu możliwe i zasadne byłoby odtworzenie średniowiecznej siatki pojęciowej. Zdecydowano jednak o pokazaniu staropolskiego uniwersum językowego w obrębie nazw używanych obecnie, czytelnych i jednoznacznych dla przeciętnego użytkownika współczesnej polszczyzny. Na kolejnych stronach autorka opisuje natomiast poszczególne etapy tworzenia, a następnie modyfikowania struktury pojęciowej słownika, charakteryzuje ogólnie kategorie pojęciowe i opisowe stosowane w SPJS. Podaje także precyzyjne dane liczbowe dotyczące aktualnej wersji schematu pojęciowego, z których można wyciągnąć interesujące wnioski na temat tak przedstawionego słownictwa staropolskiego. Na końcu zaś badaczka wskazuje na aż osiem możliwości wykorzystania opisanego słownika przez badaczy, a także wymienia istniejące prace językoznawcze dotyczące leksyki średniowiecznej, łącząc je z pojęciami wyodrębnionymi w SPJS. Zestawienie to pokazuje dobitnie, jak wiele można jeszcze zrobić w tym względzie, korzystając $z$ tego opracowania leksykograficznego.

Warto też zwrócić uwagę na dodatki do zasadniczej części książki, czyli wykaz publikacji poświęconych SPJS autorstwa zespołu słownikowego i jego współpracowników, listę wykonawców, a także trzy aneksy zawierające: cały schemat klasyfikacyjny słownika, przykładową kategorię pojęciową i polski przekład systemu pojęciowego R. Halliga i W. von Wartburga. Ostatni z nich wydaje się szczególnie cenny, gdyż do tej pory w polskim tłumaczeniu przytaczano tylko główne kategorie tego popularnego schematu klasyfikacyjnego, a teraz można się z nim zapoznać w całości po polsku.

Po przeczytaniu książki rodzą się refleksje na temat opisanych w niej decyzji metodologicznych podjętych przy tworzeniu SPJS. Niezwykle cenne w mojej opinii są fragmenty dotyczące decyzji o: klasyfikowaniu do określonych pojęć na poziomie jednostki leksykalnej, możliwości kilkakrotnego zaklasyfikowania danej jednostki, a także tworzenia kategorii pojęciowych schematu ,nie tylko na podstawie znaczeń jednostek leksykalnych zawartych w sstp, ale także ilustrujących je przykładów" (s. 82). Należy też docenić ogromny trud kierownik projektu i całego zespołu - wyraźnie widoczny w tym dziele leksykograficznym, a ponadto opisany w recenzowanej książce. Stworzyli oni bowiem precyzyjnie zbudowaną siatkę pojęciową, zwłaszcza że, co uwypuklono w monografii, był to proces skomplikowany i wieloetapowy. Warto podkreślić żmudne, ale bardzo wartościowe procesy weryfikacji zarówno schematu klasyfikacyjnego, jak i zaklasyfikowań, które doprowadziły do modyfikacji pierwotnej wersji i sprawiły, że stała się ona czytelniejsza i jeszcze bardziej funkcjonalna. Obecna struktura pojęciowa słownika wygląda bardzo interesująco (210 kategorii pojęciowych, 7 opisowych) i już teraz stanowi cenne narzędzie umożliwiające przeprowadzanie różnorodnych badań słownictwa średniowiecznego.

Są też zagadnienia, nad którymi można się zastanawiać. Poniższe uwagi, choć mogą sugerować rozważenie dalszego doskonalenia SPJs, nie umniejszają w żaden sposób wartości tego dzieła. Uniwersalnym problemem wszystkich autorów tworzących tego typu słowniki jest bowiem subiektywizm, zarówno budowy schematu klasyfikacyjnego, jak i procesu 
przyporządkowania do niego jednostek językowych ${ }^{3}$. Decyzje podejmowane przez ich twórców mogą być różnie oceniane przez użytkowników w zależności od indywidualnych preferencji, co nie ominęło nawet najbardziej znanych klasyfikacji tego typu. W aktualnej wersji SPJS w obrębie jednej kategorii występują często pojęcia w szeregach, na przykład: 2.3.5.6. KSIĘGI ŚWIĘTE. REALIA PRZEDSTAWIONE W KSIĘGACH ŚWIĘTYCH, 2.2.2.1.8. ZDZIWIENIE. ZDUMIENIE. ZASKOCZENIE. Ma to na celu precyzyjne określenie jej zawartości i ułatwienie użytkownikowi wyszukiwania, zwłaszcza że niejednokrotnie, co podkreśla B. Sieradzka-Baziur, trudno wyznaczyć precyzyjne granice między pojęciami. Na zalety, ale także ewentualne wady tego rozwiązania zwraca uwagę sama autorka, pisząc, że „schemat klasyfikacyjny byłby bardziej przejrzysty, gdyby kategoria ta została nazwana KSIĘGI śwIĘTE, ale nie informowałaby w sposób wystarczający, co można odnaleźć w jej obrębie" (s. 88). Twórcy zdecydowali, by schemat w SPJS rozbudowywać horyzontalnie w przeciwieństwie do struktury pojęciowej R. Halliga i W. von Wartburga, która ma charakter zdecydowanie bardziej wertykalny. Łączenie bliskich pojęć w ramach jednej kategorii jest częstokroć dobrym pomysłem ze względu choćby na przytoczone powyżej argumenty. Gdy jednak kategorie te obejmują liczny materiał językowy, rozbudowanie wertykalnie schematu SPJS wydaje się także właściwe ${ }^{4}$. Przykładowo: zamiast licznie wypełnionej materiałem językowym kategorii 2.1.1. POCZĄTEK ŻYCIA. NARODZINY. KOLEJNE ETAPY ŻYCIA. ŚMIERĆ można stworzyć kategorię ETAPY ŻYCIA, wewnętrznie podzieloną na podkategorie dotyczące konkretnych rozdziałów ludzkiej egzystencji. Tego typu funkcjonalne w mojej opinii podziały twórcy słownika stosują częstokroć, chociażby przy kategorii 2.1.4. ZMYSŁY podzielonej na pięć podkategorii opisujących poszczególne z nich. Dalszy podział kategorii pojęciowych bardzo licznie wypełnionych byłby więc uzasadniony ze względu na spójność budowy schematu, a zwłaszcza na jego funkcjonalność. Jednostki leksykalne przyporządkowane do kategorii pojęciowych wyświetlają się bowiem razem w porządku alfabetycznym, co może nieco utrudniać wyszukiwanie komuś, kto chciałby znaleźć słownictwo dotyczące określonego pojęcia (np. starości).

Choć rację ma autorka, że nadmierne rozdrabnianie struktury pojęciowej może sprawić, że stanie się ona zawiła, użytkownik słownika elektronicznego zazwyczaj korzysta z wyszukiwarki, dzięki której znajduje interesujące go pojęcie lub prowadzący do niego wyraz. Zamknięta lista słownictwa, którą dysponują autorzy (w przeciwieństwie do innych słowników tego typu, gdzie ogólny schemat służy klasyfikacji nieznanych jednostek), umożliwia teoretycznie zbudowanie podziału względnie równomiernego co do stopnia szczegółowości, choć to nie szerokość kategorii powinna być kryterium nadrzędnym. Zdaję sobie jednak sprawę, iż jest to proces niełatwy i długotrwały (w sPJs klasyfikacji poddano 44177 autosemantycznych jednostek leksykalnych). Zapewne tego typu modyfikacje będą jeszcze dokonywane, gdyż badaczka

3 Jestem tego szczególnie świadoma jako autorka systemu klasyfikacyjnego umożliwiającego podział tematyczny w słowniku współczesnego języka polskiego i osoba dokonująca od lat takiej klasyfikacji.

4 Czasem widać dysproporcje między stopniem szczegółowości jego budowy, gdyż w niektórych niezbyt licznych pod względem jednostek kategoriach pojęciowych dokonano dokładniejszych podziałów (np. WYCHOWANIE czy MEDIACJA). Jak można przeczytać na stronie 84, ostatnia z nich powstała na skutek dodatkowych analiz i jako przykładowa została zamieszczona na końcu książki, stąd może jest o wiele bardziej szczegółowa i zapowiada tym samym kolejne podziały tego typu. 
136 | RECENZJe | JęZYK POLSKI | CI 3

często podkreśla na łamach książki, że „Z założenia schemat klasyfikacyjny SPJs ma charakter zmienny i otwarty” i że dąży do „opracowania optymalnej struktury, w której powinny się znaleźć pojęcia konieczne i wystarczające" (s. 83-84). Przy okazji refleksji o rozbudowanych nazwach kategorii wskazuje ona właśnie, iż „uszeregowane pojęcia można też traktować jako propozycję stworzenia kategorii podrzędnych" (s. 88).

Choć książka nie jest długa, z każdej jej strony przebija rzetelność i dokładność opisu, co wydaje się cechą charakterystyczną zarówno autorki wraz z zespołem, jak i - w konsekwencji - opisywanego słownika. W monografii znajdziemy liczne tabele, wyliczenia oraz opisy poparte danymi liczbowymi i konkretnymi przykładami z SPJS. Badaczka, co szczególnie cenne, precyzyjnie definiuje stosowane przez siebie terminy i dokładnie tłumaczy, dlaczego podjęto określone decyzje metodologiczne co do budowy i zasad funkcjonowania opisywanego dzieła. Książka ta koncentruje się de facto na jednym słowniku, gdyż przybliża i charakteryzuje zarówno prace nad sPJs, jak i jego aktualny wygląd (wersja z 30.06.2020). Jak słusznie zauważyła jej recenzentka Magdalena Derwojedowa (co można przeczytać na tylnej okładce), należy ona więc do nurtu zwanego w literaturze popularnej making of, czyli dzieł opisujących powstanie innych dzieł. Dzięki temu mamy do czynienia z teoretycznym opisem problemów metodologicznych przy tworzeniu słownika pojęciowego na materiale historycznym, a zarazem $\mathrm{z}$ bardzo konkretnymi propozycjami ich rozwiązania, które zostały zweryfikowane w praktyce. Dlatego też prezentowana pozycja z powodzeniem może się stać pomocą przy tworzeniu analogicznych słowników obejmujących na przykład kolejne epoki rozwoju polszczyzny, w których obiektem podziału będzie znana lista słownictwa. Książka ta uzupełnia też polską refleksję naukową na temat leksykografii onomazjologicznej i elektronicznej, semantyki historycznej i współczesnych słowników gromadzących leksykę dawną. 